\title{
BODY MEASUREMENTS OF BLACK SLAVONIAN PIG
}

\author{
Katarina Latin, Tajana Petrić, N. Raguž, D. Karolyi, V. Klišanić, \\ S. Menčik, Ž. Mahnet, B. Lukić
}

\begin{abstract}
Summary
The Black Slavonian pig is an autochthonous pig breed in Croatia, which has recorded a continuous growth of the population followed by the higher number of breeders in recent years. The increase in population has removed the Black Slavonian breed from the category of endangered local breeds. The consequences of such a significant increase in population size in local breeds are often a high level of inbreeding, but also a high variability of the external traits of breeding individuals. Given that the main goal of the Breeding Program for Black Slavonian pigs is to preserve its phenotypic traits and breed-specific features, the paper presents the results of external traits analysis at 10 different points on the body, on a sample of 102 animals, aged between 10 and 24 months. Estimated mean values for wither's height were $65 \mathrm{~cm}$ and $64 \mathrm{~cm}$ in boars and sows, respectively. Average body length was $128 \mathrm{~cm}$ for boars, and $126 \mathrm{~cm}$ for sows. The heart girth was $114 \mathrm{~cm}$ for both categories, while the height at the sacrum was $72 \mathrm{~cm}$ (boars), and $71 \mathrm{~cm}$ (sows). These results indicate very small or insignificant differences between male and female individuals, and refer that the body measurements of Black Slavonian pigs have not changed significantly in relation to its formation and development over time, as well as in relation to other local breeds from the neighbouring regions. With this in mind, selection work should be focused on control and preservation. Furthermore, the paper gives an overview of the population throughout history, as well as breeding practices.
\end{abstract}

Key words: Black Slavonian pig, external traits, body measurements, variability, phenotype

\section{Introduction}

Together with the cultural and historical heritage, local and endangered breeds form the basis for the preservation of biological diversity and representation of national heritage. The Black Slavonian pig breed originated in the Eastern Slavonia in the second half of the 19th century. The origin of the breed is connected with breeding and selection activities of the landowner Karl Pffeifer in the area of Orlovnjak, who systematically mated local Swallow-bellied Mangulica sows with English Berkshire boars. Hrasnica et al. (1964) described Mangulica as a relatively short and wide pig, with straight and gentle legs, lower rump angle (lower pin than hip bones), dropped ears with curly dark brown hair on the back and yellowish-white belly. Berkshire was

\footnotetext{
Katarina Latin, M.Sc. Black Slavonian Pig Breeders Association "Fajferica", Đakovo,

Tajana Petrić, M.Sc. Ecoland Herbs\&Spices, Haller Str. 20, 74549 Wolpertshausen, Germany,

Nikola Raguž, PhD. Faculty of Agrobiotechnical Sciences Osijek, Vladimira Preloga 1, 31000 Osijek,

Danijel Karolyi PhD. Faculty of Agriculture Zagreb, Svetošimunska cesta 25, 10000 Zagreb,

Vedran Klišanić, M.Sc. Ministry of Regional Development and EU Funds, Miramarska cesta 22, 10000 Zagreb,

Sven Menčik, PhD. Faculty of Veterinary Medicine, Heinzelova 55, 10000 Zagreb,

Željko Mahnet, M.Sc. Ministry of Agriculture, Ilica 101, 10000 Zagreb,

Boris Lukić, PhD. Faculty of Agrobiotechnical Sciences Osijek, Vladimira Preloga 131000 Osijek,

e-mail: boris.lukic@fazos.hr - Corresponding author.
} 
described as a medium-sized, wide pig with short legs, with dense and thick black hair. Due to their dark pigments, both of these breeds were more resistant to direct sunlight. Pffeifer then selected the best female animals, which were mated with the boars of the American Poland China, a breed known for its large body frame, leanness and fertility. Every ten years, he would import 10 boars of the American Poland China breed and then would select the best animals for further breeding (Kurbanović, 1943). Following the world trends in pig breeding, Pffeifer used his selection skills to create more advanced pigs in terms of fertility, leanness and early maturity compared to contemporary local breeds of pigs, something he finally succeeded in doing with the Black Slavonian pig (Ilančić, 1939).

Exterior traits of the Black Slavonian pig in the period from the mid-20 th century to the present day

Unlike modern breeds of pigs and hybrids, the local breeds are much more resistant and adapt faster to modest environmental conditions due to less intensive and often present natural selection. Hrasnica et al. (1964) stated that the Black Slavonian pig was initially bred on larger farms, and over time their breeding expanded to smaller farms due to their ability to adapt to indoors, or to outdoors pastures.

Most literary records on the Black Slavonian pig, starting from the beginning of the twentieth century until today, were mainly focused on description and analysis of reproductive and production traits, and, therefore, it would be difficult and inappropriate to draw conclusions about the body measurements of Black Slavonian pigs for that period. In the absence of precise data on body measurements, using the information on the exterior traits from several available historical sources, we can get a partial insight into their body measurements. Kurbanović (1943) stated that concerning absolute and relative body measurements, the Black Slavonian pig is mostly similar to the hairy Mangulica, while in terms of reproductive and production traits it is mostly similar to Berkshire and Poland China. Pribićević (1950) measured 9 sows of Black Slavonian pigs, aged 3 years, and showed that wither's height was $69.4 \mathrm{~cm}$, sacrum height $72.4 \mathrm{~cm}$, body length $92.7 \mathrm{~cm}$, chest depth 39.7, chest width 31.7 , heart girth $117.9 \mathrm{~cm}$, and shin bone girth $14.9 \mathrm{~cm}$. Hrasnica et al. (1964.) described the Black Slavonian pig as small to medium-sized pig with a short body length, flat back, narrow and shallow chest. The legs were short and straight, while the thighs were well developed.

Half a century later, Uremović (2004) similarly described the breed and stated that it belongs to the combined fat-meat type of pig characterized by a short and stocky body, large and wide head, rounded chest and shorter neck. The skin of the Black Slavonian breed is ashy gray and covered with a black shiny hair. The above descriptions from different periods indicate that the breed did not change significantly when it comes to the most relevant exterior traits from the first half of the 20th century until today. The only feature where a visible difference is mentioned is the description of the chest, as according to Hrasnica et al. (1964). It is described as narrow and wide, while Uremovic describes it (2004) as deep and wide. Given that this is a subjective description, it is very likely that the discrepancy in descriptions was a result of different external impressions, because pigs in general, compared to the previous period, look significantly different. 


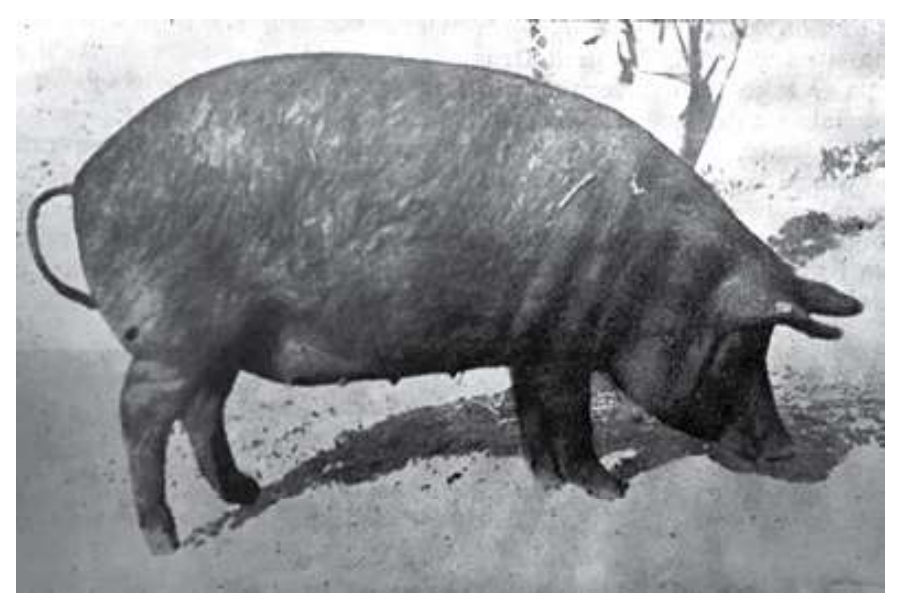

Figure 1 Sow of the Black Slavonian pig (Hrasnica et al. 1964)

Slika 1. Krmača crne slavonske svinje (Hrasnica et al. 1964.)

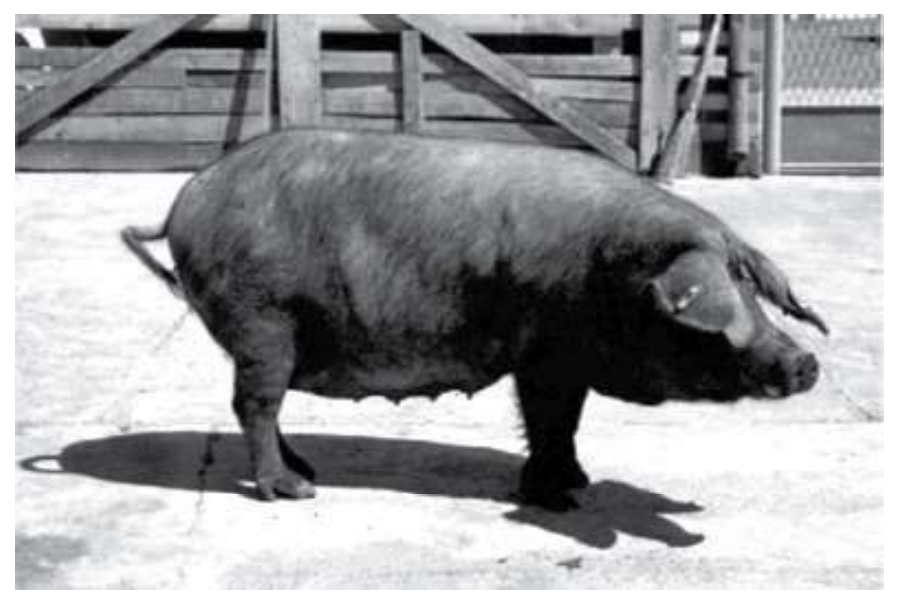

Figure 2 Sow of the Black Slavonian pig (Barać et al. 2011)

Slika 2. Krmača crne slavonske svinje (Barać et al. 2011.)

\section{Population size of the Black Slavonian pig}

The Black Slavonian pig breed was the most widespread breed in Croatia in the first half of the $20^{\text {th }}$ century. Statistical data from 1958 stated that the Black Slavonian pig was the most widespread breed in the area of Slavonia, Syrmia and Vojvodina, with a total of 300,000 animals in the former Yugoslavia (Hrasnica et al., 1958). At that time, it was considered a breed with the best economic traits due to its early maturity, higher fertility, fattening and meat quality, as well as its good adaptation for breeding on smaller farms (Ilančić, 1939). However, Hrasnica et al. (1958) stated that high number of smaller and stunted Black Slavonian pigs was present at the beginning of the World War II, mainly due to poor nutrition and an extensive way of keeping which was more adapted for Mangulica. In addition, the undesirable appearance of lighter, pink or white markings on the legs and snout was often observed, which was associate with continuous and unplanned mating of the Black Slavonian pig with Berkshire. Moreover, 
such undesirable external traits can nowadays often be observed in the Black Slavonian pig, which is why, animals that have white markings on the body must be excluded from further breeding, according to the current breeding program (Breeding program, 2018). Such breeding practices have certainly had an impact on the exterior characteristics and external appearance of the Black Slavonian pig over a long period of time.

Furthermore, the population size has declined significantly in line with trends in pig production (Lukić et al., 2018) and imports of more modern breeds of pigs, all the way from the mid-20th century to the 1990s (Lukić et al. 2020). As a result of these trends and the war in Croatia, since the mid-1990s (HPA Report 1996), the population consisted of only six boars and 46 sows. With the arrival of new trends on the market, the population recovered and grew to 2495 sows and 193 boars (HPA Report, 2019), which is an increase of almost 50 times in 24 years.

It is expected that such a narrow "bottleneck" of the population size will certainly have effects on the exterior traits, which apparently didn't happen in the case of the Black Slavonian pig, as concluded by analysing old and recent literature.

The aim of this paper was to compare the body measurements of today's Black Slavonian pigs with those from the available historical records, to analyse the actual data collected for the purpose of developing a breeding program adopted in 2018, as well as compare them with other local breeds of European countries. Breeding goals of this breed are aimed at preserving phenotypic traits and genetic variation, in accordance with the traditional keeping practices. Hence, defining the breed standard, i.e., desirable and undesirable external traits is highly important for conducting of systematic breeding and selection activities. Finally, the paper gives a brief overview of the population size throughout history, which to some extent may have affected the external traits of the Black Slavonian pig.

\section{Material and methods}

Measurements were carried out on the 7 family farms in Slavonia and north-western Croatia. The analysis was performed on a total of 102 animals (in average 15 animals per farm). Body measurements were assessed on 21 boars, 45 gilts and 36 sows. Body measurements included 10 different external traits (measures) and weighing of each tested animal.

Measured external traits were: wither's height (vertical height to the ground, along the front leg, to the highest point of the withers), sacrum height (vertical height to the ground, along the rear leg, to the highest point of the sacrum), heart girth (measured behind the front legs), body length (length from the base of the ears to the base of the tail), carcass length (length from the middle of the scapular-shoulder joint to the sciatic hump - tuber ischiadicum), rump width (width between lateral humps - tuber coxae), rump length (length from the anterior edge of the lateral hump - tuber coxae to the posterior edge of the sciatic hump - tuber ischiadicum), head length (length from snout to occiput), length of ears (length from root to tip of ear), and tail length (length from base to tip of tail).

Each animal was weighed individually on a livestock scale at the beginning of the exterior trait measurement. The Lydtin rod was used to determine following body measurements: 
wither's height, sacrum height, rump width, rump length, and carcass length. To determine body measurements, i.e. heart girth, body length, head length, ear length and tail length, the measuring tape was used. During the analysis, the hair and skin colour for each individual were determined subjectively. For the purpose of this research, representative individuals (healthy with good overall condition) of the breed were selected, whose data on age, productivity and origin were provided by the breeders and the Croatian Agricultural Agency.

Statistical analysis included mean values estimation by linear regression (body weight used as an estimator (independent) variable, and all body measurements as separate dependent variable). To obtain estimated values for analysed body measurements, a fixed body mass of 90 and $115 \mathrm{~kg}$ was used. This approach was chosen instead of group design as the population size of Black Slavonian was too small to collect representative number of sows and boars at exact body mass. Furthermore, standard errors of estimated values, coefficient of variability, minimum and maximum values of all analysed traits, as well as correlation analysis to further verify the validity of the analyses were calculated. All analyses were performed using SAS Institute Inc., SAS 9.4. 2013. and Microsoft Corporation. (2018) Microsoft Excel software.

\section{Results and discussion}

The obtained results are classified into categories by sex and age, as shown in Table 1. In both categories, the largest difference was found for the body length $(126 \mathrm{~cm})$ with estimated standard error of $\pm 6.7 \mathrm{~cm}$ for sows, while for boars the body length was $128 \mathrm{~cm}$, with a standard error of $\pm 5.9 \mathrm{~cm}$. The smallest difference was found for the rump width, which was slightly higher in sows $(27 \mathrm{~cm}$; standard error $\pm 2.1 \mathrm{~cm})$ than in boars $(26 \mathrm{~cm}$; standard error $\pm 1,4 \mathrm{~cm})$., A small difference between the male and female external traits can be noticed from the abovementioned results. Boars were found to have higher values of wither's height, sacrum height, body length, carcass length, and head length compared to female categories. The head in both genders had a concave profile. Female categories had higher rump width and rump length values, while the heart girth, ear length, tail length, skin colour and hair values were relatively uniform. Although the values coincide with the previous reports (Pribićević, 1950), it is important to note that the confidence intervals of estimated means between male and female categories overlapped for most traits, so it would be advisable to perform the analysis on a significantly larger sample to accurately determine the differences between genders.

The skin colour of the male and female categories was mostly dark grey. The hair in both categories was distributed according to density (thick or sparse), length (long or short) and curl (straight or curly). The most common combination in both female categories (42 individuals or $52 \%$ ) was sparse, short and straight hair. Thick, long and curly hair was the rarest combination ( 2 individuals or $2 \%$ ) in the female category. In the male category, the condition was opposite, i.e., the most common combination (9 individuals or $42 \%$ ) was thick, long and curly hair. The rarest combination in the male category was sparse, long and curly, as only 1 animal had it. Due to the frequent occurrence of a bitten tail, the results for tail length in both categories were excluded as incomplete. 
Table 1 Body measurements of breeding animals (estimated mean values, standard errors (in parentheses) and coefficients of variability

Tablica 1. Tjelesne mjere rasplodnih kategorija (procijenjene srednje vrijednosti, standardne pogreške (u zagradama) i koeficijenti varijabilnosti

\begin{tabular}{|c|c|c|c|c|c|c|}
\hline \multirow{2}{*}{$\begin{array}{l}\text { TRAIT } \\
\text { MJERA }\end{array}$} & \multicolumn{2}{|c|}{$\begin{array}{l}\text { Female category } \\
\text { Ženske kategorije }\end{array}$} & \multirow{4}{*}{$\mathrm{CV}^{*}$} & \multicolumn{2}{|c|}{$\begin{array}{c}\text { Male category } \\
\text { Muške kategorije }\end{array}$} & \multirow{4}{*}{$\mathrm{CV}^{*}$} \\
\hline & $\begin{array}{c}\text { Gilts } \\
\text { Nazimice }\end{array}$ & $\begin{array}{c}\text { Sows } \\
\text { Krmače }\end{array}$ & & $\begin{array}{l}\text { Young boars } \\
\text { Nerastići }\end{array}$ & $\begin{array}{c}\text { Boars } \\
\text { Nerasti }\end{array}$ & \\
\hline $\begin{array}{l}\text { Age } \\
\text { Starost }\end{array}$ & $\begin{array}{c}10 \text { months/ } \\
\text { mjeseci }\end{array}$ & $\begin{array}{c}\text { 15-18 months/ } \\
\text { mjeseci }\end{array}$ & & $\begin{array}{c}10 \text { months/ } \\
\text { mjeseci }\end{array}$ & $\begin{array}{l}\text { 15-18 months/ } \\
\text { mjeseci }\end{array}$ & \\
\hline $\begin{array}{l}\text { Body mass } \\
\text { Tjelesna masa }\end{array}$ & $90 \mathrm{~kg}$ & $115 \mathrm{~kg}$ & & $90 \mathrm{~kg}$ & $115 \mathrm{~kg}$ & \\
\hline $\begin{array}{l}\text { Wither's height } \\
\text { Visina grebena }\end{array}$ & $\begin{array}{c}61 \mathrm{~cm} \\
( \pm 3,9 \mathrm{~cm})\end{array}$ & $\begin{array}{c}64 \mathrm{~cm} \\
( \pm 3,9 \mathrm{~cm})\end{array}$ & 8,10 & $\begin{array}{c}61 \mathrm{~cm} \\
( \pm 4,0 \mathrm{~cm})\end{array}$ & $\begin{array}{c}65 \mathrm{~cm} \\
( \pm 4,0 \mathrm{~cm})\end{array}$ & 14,40 \\
\hline $\begin{array}{l}\text { Sacrum height } \\
\text { Visina križa }\end{array}$ & $\begin{array}{c}68 \mathrm{~cm} \\
( \pm 3,4 \mathrm{~cm})\end{array}$ & $\begin{array}{c}71 \mathrm{~cm} \\
( \pm 3,4 \mathrm{~cm})\end{array}$ & 7,20 & $\begin{array}{c}69 \mathrm{~cm} \\
( \pm 2,5 \mathrm{~cm})\end{array}$ & $\begin{array}{c}72 \mathrm{~cm} \\
( \pm 2,5 \mathrm{~cm})\end{array}$ & 8,38 \\
\hline $\begin{array}{l}\text { Heart girth } \\
\text { Opseg prsa }\end{array}$ & $\begin{array}{c}104 \mathrm{~cm} \\
( \pm 4,7 \mathrm{~cm})\end{array}$ & $\begin{array}{c}114 \mathrm{~cm} \\
( \pm 4,7 \mathrm{~cm})\end{array}$ & 11,70 & $\begin{array}{c}105 \mathrm{~cm} \\
( \pm 3,8 \mathrm{~cm})\end{array}$ & $\begin{array}{c}114 \mathrm{~cm} \\
( \pm 3,8 \mathrm{~cm})\end{array}$ & 14,88 \\
\hline $\begin{array}{l}\text { Body length } \\
\text { Duljina tijela }\end{array}$ & $\begin{array}{c}117 \mathrm{~cm} \\
( \pm 6,7 \mathrm{~cm})\end{array}$ & $\begin{array}{c}126 \mathrm{~cm} \\
( \pm 6,7 \mathrm{~cm})\end{array}$ & 10,90 & $\begin{array}{c}120 \mathrm{~cm} \\
( \pm 5,9 \mathrm{~cm})\end{array}$ & $\begin{array}{c}128 \mathrm{~cm} \\
( \pm 5,9 \mathrm{~cm})\end{array}$ & 13,16 \\
\hline $\begin{array}{l}\text { Carcass length } \\
\text { Duljina trupa }\end{array}$ & $\begin{array}{c}74 \mathrm{~cm} \\
( \pm 6,3 \mathrm{~cm})\end{array}$ & $\begin{array}{c}80 \mathrm{~cm} \\
( \pm 6,3 \mathrm{~cm})\end{array}$ & 11,80 & $\begin{array}{c}75 \mathrm{~cm} \\
( \pm 5,2 \mathrm{~cm})\end{array}$ & $\begin{array}{c}82 \mathrm{~cm} \\
( \pm 5,2 \mathrm{~cm})\end{array}$ & 17,79 \\
\hline $\begin{array}{l}\text { Rump width } \\
\text { Širina zdjelice }\end{array}$ & $\begin{array}{c}25 \mathrm{~cm} \\
( \pm 2,1 \mathrm{~cm})\end{array}$ & $\begin{array}{c}27 \mathrm{~cm} \\
( \pm 2,1 \mathrm{~cm})\end{array}$ & 15,30 & $\begin{array}{c}24 \mathrm{~cm} \\
( \pm 1,4 \mathrm{~cm})\end{array}$ & $\begin{array}{c}26 \mathrm{~cm} \\
( \pm 1,4 \mathrm{~cm})\end{array}$ & 18,19 \\
\hline $\begin{array}{l}\text { Rump length } \\
\text { Duljina zdjelice }\end{array}$ & $\begin{array}{c}27 \mathrm{~cm} \\
( \pm 3,7 \mathrm{~cm})\end{array}$ & $\begin{array}{c}29 \mathrm{~cm} \\
( \pm 3,7 \mathrm{~cm})\end{array}$ & 18,50 & $\begin{array}{c}26 \mathrm{~cm} \\
( \pm 3,0 \mathrm{~cm})\end{array}$ & $\begin{array}{c}28 \mathrm{~cm} \\
( \pm 3,0 \mathrm{~cm})\end{array}$ & 25,57 \\
\hline $\begin{array}{l}\text { Head length } \\
\text { Duljina glave }\end{array}$ & $\begin{array}{c}25 \mathrm{~cm} \\
( \pm 3,4 \mathrm{~cm})\end{array}$ & $\begin{array}{c}26 \mathrm{~cm} \\
( \pm 3,4 \mathrm{~cm})\end{array}$ & 15,00 & $\begin{array}{c}26 \mathrm{~cm} \\
( \pm 2,4 \mathrm{~cm})\end{array}$ & $\begin{array}{c}28 \mathrm{~cm} \\
( \pm 2,4 \mathrm{~cm})\end{array}$ & 15,83 \\
\hline $\begin{array}{l}\text { Ear length } \\
\text { Duljina ušiju }\end{array}$ & $\begin{array}{c}22 \mathrm{~cm} \\
( \pm 2,5 \mathrm{~cm})\end{array}$ & $\begin{array}{c}23 \mathrm{~cm} \\
( \pm 2,5 \mathrm{~cm})\end{array}$ & 12,50 & $\begin{array}{c}22 \mathrm{~cm} \\
( \pm 2,6 \mathrm{~cm})\end{array}$ & $\begin{array}{c}23 \mathrm{~cm} \\
( \pm 2,6 \mathrm{~cm})\end{array}$ & 15,55 \\
\hline
\end{tabular}

*Coefficient of variability for the observed body measure

* Koeficijent varijabilnosti za promatranu tjelesnu mjeru

In addition to the standard error, a coefficient of variation was used as a measure of dispersion, which represents the relative deviation from the mean. The table shows the coefficient of variability CV (\%) for all body measurements of boars and sows of Black Slavonian pigs. Boars were found to vary more than sows for wither's height, heart girth, carcass length, rump width, and rump length, according to the values of coefficient of variation. However, the number of samples of boars analysed was significantly lower (21/81) compared to sows, which is important to consider while comparing these values. The highest coefficient of variation was characteristic for tail length, rump length, and rump width in both groups. Tail length was excluded from the results because pigs had their tails largely bitten off, which is why extremely 
high variability was obtained. The rump length and rump width, on the other hand, were traits with the highest possibility of measurement error, because of the physical condition of the animal (the lateral and sciatic humps are difficult to feel in fatter animals). The lowest coefficient of variation, determined at a level below $10 \%$, was the sacrum height, with values $7.2 \%$ and $8.38 \%$ in sows and boars respectively.

\section{Comparison with other similar foreign local breeds}

While numerous scientific papers and literature are available for the production traits of Black Slavonian pigs, for the body measurements the literature is scarce, therefore it cannot be compared or precisely analysed. But if we compare it with similar local breeds from other European countries, such as Swabian-Hall pigs from Germany (Petig et al., 2018), Bisaro pigs from Portugal (Silva et al., 2018), Iberian pigs from Spain (Nieto et al., 2019) or Black Sicilian from Italy (Bozzi et al., 2019), the Black Slavonian pig breed was predominantly lower in wither's height, had a shorter body, lower body weight and slightly smaller heart girth.

The German local breed Swabian-Hall pig, was bigger than the Black Slavonian pig in terms of body measurements, as her average body weight was $280 \mathrm{~kg}$ for sows and $350 \mathrm{~kg}$ for boars. Also, the higher value was found for the wither's height, $86 \mathrm{~cm}$ and $95 \mathrm{~cm}$ in average for sows and boars, respectively (Petig et al., 2018). However, it is important to point out that the age of the animals was not stated in this study, which highly affects the body measurements. Comparing the exterior traits of the adult categories of the Black Slavonian pig breed with the Portuguese local indigenous breeds such as the Bisaro and Black Alentejano pig, it was observed that the Black Slavonian pig was smaller in size but approximately equal in body weight.

Silva et al. (2018) showed that the wither's height was $97 \mathrm{~cm}$ for boars and $89 \mathrm{~cm}$ for sows for a Bisaro pig, which makes the Black Slavonian pig lower in the wither's height. Adult females reach a body weight of $150 \mathrm{~kg}$, while adult males reach up to $180 \mathrm{~kg}$, which is also usual for the Black Slavonian pig breed.

According to Nieto et al. (2019) Spanish Iberian pig reaches a body weight of 155 to $165 \mathrm{~kg}$ for adult categories at the age of 18 months, which is approximately the body weight of adult individuals of the Black Slavonian pig breed. The wither's height of Iberian pig sows is higher than the wither's height of the Black Slavonian pig, i.e. $77.3 \mathrm{~cm}$ for sows, and $79.8 \mathrm{~cm}$ for boars.

The Black Sicilian pig has a similar morphology in terms of robust build and medium size, body size, coat colour and hair as the Black Slavonian pig breed (Bozzi et al., 2019). The wither's height of a Black Sicilian pig was 60 to $65 \mathrm{~cm}$ for adult categories, which is very similar to Black Slavonian pig breed (Table 1). Also, the body weights achieved by adult categories were relatively similar, as Bozzi et al. (2019) stated that the Black Sicilian pig for adult categories reached a weight of $130 \mathrm{~kg}$ for females, and $150 \mathrm{~kg}$ for males.

Comparison of the Black Slavonian pig with the local breeds from geographically closer countries or regions showed high similarity in terms of exterior traits. For example, the Turopolje pig had approximately the same values as the Black Slavonian pig for withers height, heart girth and ear length. However, the Black Slavonian adult pigs reached a higher body weight compared to the Turpolje pig, which in adult categories reached a weight of about $90 \mathrm{~kg}$ (Karolyi et al., 2019). 
Furthermore, Savić et al. (2019) showed that the Moravka adult pigs, with a body weight of $100 \mathrm{~kg}$, which is similar to the weight of Black Slavonian pigs from this study, had approximately same values of wither's height, i.e. $62.4 \mathrm{~cm}$ for adult female, and $63.4 \mathrm{~cm}$ for adult male categories.

According to the above comparisons, we can observe certain differences in body measurements, for example the wither's height between the Black Slavonian pig and other European local breeds. However, if we compare the local breeds of geographically closer countries and areas where the Black Slavonian pig originated, we can see that certain body measures are very similar, often the same.

The analysis of the available literature on the Black Slavonian pig and her body measurements during its origin and development as listed in Table 1, shows that the Black Slavonian pig breed has not changed significantly in main body measurements over the past 70 years. Also, from the above comparisons, it can be concluded that the Black Slavonian pig breed is similar to the local breeds from the same or close area of origin, in its external traits.

The first Breeding Program for the Black Slavonian Pig Breed, which was adopted at the end of 2012 by the Association of Breeders of the Black Slavonian Pig Breed "Fajferica", established selection criteria for the selection of future breeding animals. These criteria were upgraded by the breeding program in 2018 , according to which, in addition to testing for boars, gilts should also be tested. Such practices represent important breeding principles, where the selection of potential future parents is based on exterior traits and body measurements (shape, size and expression of breed-specific features), consistent with the phenotypic traits specific to the Black Slavonian pig. In accordance with the positive trend of population growth in recent decades, the systematic activities of the Association of Black Slavonian Pig Breeders "Fajferica", as well as increasing breeders' interest in economic exploitation of the breed, it was necessary to analyze the external traits of this breed. The results of this research will significantly improve breeding and selection activities, facilitate breeders' selection decisions in certain time-point, and positively affect the reproduction by achieving more uniform animals, not only in terms of external traits, but also in terms of production or carcass traits.

\section{Conclusion}

Based on this research on body measurements, the Black Slavonian pig can be described as a medium-sized pig, medium-long head with concave profile, medium-sized to large ears bent forward, short and thin-legged, and lower rump angle. According to the above comparisons, the research shows that local breeds of geographically closer countries had very similar, often equal external traits i.e. withers height, ear length and heart girth. Based on this research, it was found that there are certain differences in the body measurements of mature individuals of local European breeds and the Black Slavonian pig, which was mostly lower in withers height, shorter in body length and smaller in heart girth. Considering that the population of Black Slavonian pigs in the Republic of Croatia has been continuously growing in the last 20 years, it is necessary to systematically monitor and select breeding animals on the basis of high-quality standards of body measurements. In this way, breeding and selection practice will be able to systematically control and monitor changes in the population, preserve its genetic diversity and its genetic potential within the breed-specific features. 


\section{LITERATURE}

1. Barać, Z., Lj. Bedrica, M. Čačić, M. Dražić, M. Dadić i sur. (2011): Zelena knjiga izvornih pasmina Hrvatske/ Green book of indigenous breeds of Croatia. Ministarstvo zaštite okoliša i prirode, Državni zavod za zaštitu prirode, Hrvatska poljoprivredna agencija, Nacionalni park Krka. Zagreb.

2. Bozzi, R., Gallo, M., Geraci, C., Fontanesi, L., Batorek-Lukač, N. (2019): Nero Siciliano Pig, European Local Pig Breeds - Diversity and Performance. A study of project Treasure. IntechOpen. doi:http://dx.doi. org/10.5772/intechopen.84438

3. Hrasnica, F., Ilančić, D., Milosavljević, S., Pavlović, S., Rako, A., Šmalcelj, I. (1958): Specijalno stočarstvo, I. izdanje. Univerzitet u Beogradu, Sveučilište u Zagrebu i Univerzitet u Sarajevu, Beograd.

4. Hrasnica, F., Ilančić, D., Milosavljević, S., Pavlović, S., Rako, A., Šmalcelj, I. (1964): Specijalno stočarstvo, II. Izdanje. Univerzitet u Beogradu, Sveučilište u Zagrebu i Univerzitet u Sarajevu, Beograd.

5. Hrvatska Poljoprivredna Agencija (HPA): Annual report, 1996.

6. Hrvatska Poljoprivredna Agencija (HPA): Annual report, 2019.

7. Ilančić, D. (1939): Prinos poznavanju plodnosti i dužine bređosti crnog slavonskog svinjčeta (Pffeiferice). Veterinarski arhiv 8, 404-414.

8. Karolyi, D., Luković, Z., Salajpal, K., Škorput D., Vnučec, I., Mahnet, Ž., Klišanić, V., Batorek-Lukač, N. (2019): Turopolje Pig (Turopoljska svinja). European Local Pig Breeds - Diversity and Performance. A study of project Treasure. IntechOpen. doi:http://dx.doi.org/10.5772/intechopen.83782

9. Kurbanović, M. (1943): Uzgoj svinja; po predavanjima prof.dr. Nikole Ritzoffy. Zbirka rijetkosti R 7443 , $82-85$.

10. Lukić, B., Ferenčaković, M., Šalamon, D., Čačić, M., Orehovački, V., lacolina, L., Curik, I. and Cubric-Curik, V. (2020): Conservation Genomic Analysis of the Croatian Indigenous Black Slavonian and Turopolje Pig Breeds. Frontiers in Genetics. 11:261.. doi: 10.3389/fgene.2020.00261

11. Lukić, B., Raguž, N., Karolyi, D., Kranjac, D., Luković, Z., Mahnet, Ž., Steiner, Z. (2018): Uzgoj crne slavonske svinje - Priručnik za uzgajivače i student. Udruga uzgajivača crne slavonske svinje Slavonije, Baranje i zapadnog Srijema "FAJFERICA", Osijek.

12. Nieto, R., García-Casco, J., Lara, L., Palma-Granados, P., Izquierdo, M., Hernandez, F., Dieguez, E., Luis Duarte, J., Batorek-Lukač, N., (2019): Ibérico (Iberian) Pig, European Local Pig Breeds - Diversity and Performance. A study of project Treasure. IntechOpen. doi http://dx.doi.org/10.5772/intechopen.83765

13. Petig, M., Zimmer, C., Bühler, R., Batorek-Lukač, N., (2019): Schwäbisch-Hällisches Pig, European Local Pig Breeds - Diversity and Performance. A study of project Treasure. IntechOpen. doi http://dx.doi. org/10.5772/intechopen.83780

14. Pribičević, S. (1950): Svinjarstvo, Crna slavonska svinja (fajferica). Izdavačko produzeće Narodne republike Srbije, Beograd, 49-51.

15. Silva, S.J., Araújo P.J., Cerqueira, O.J., Pires, P., Alves, C., Batorek-Lukač, N., (2019): Bísaro pig, European Local Pig Breeds - Diversity and Performance. A study of project Treasure. IntechOpen. doi http://dx. doi.org/10.5772/intechopen.83759

16. Savić, R., Radović, Č., Petrović, M., Gogić, M., Radojković, D., Batorek-Lukač, N. (2019): Moravka Pig, European Local Pig Breeds - Diversity and Performance. A study of project Treasure. IntechOpen. doi http://dx.doi.org/10.5772/intechopen.83777

17. Uremović, M. (2004): Crna slavonska pasmina svinja - Hrvatska izvorna pasmina, Vukovarsko -srijemska županija, Vukovar.

18. Vučevac Bajt, V., Gregurić Gračner, G., Vitković, A. (2001): Autohtone pasmine svinja na području Hrvatske, Stočarstvo 55:2001, 351- 356. 


\title{
TJELESNE MJERE CRNE SLAVONSKE SVINJE
}

\begin{abstract}
Sažetak
Crna slavonska svinja autohtona je pasmina svinja u Republici Hrvatskoj, koja posljednjih godina bilježi kontinuirani rast populacije i broja uzgajivača. Porast brojnosti populacije maknuo je crnu slavonsku pasminu iz kategorije ugroženih izvornih pasmina svinja u Republici Hrvatskoj. Posljedice takvog značajnog porasta populacije kod lokalnih pasmina kao što je crna slavonska svinja, nerijetko su visok stupanj uzgoja u srodstvu, ali i visoka varijabilnost rasplodnih jedinki u pogledu svojstava vanjštine. S obzirom da je glavni cilj Uzgojnog programa za crnu slavonsku svinja očuvati njezine fenotipske karakteristike i pasminsku specifičnost, u radu su prikazani rezultati mjerenja svojstava vanjštine, na uzorku od 102 životinje, u dobi od 10 do 24 mjeseci, na 10 različitih točaka na tijelu. Procijenjene srednje vrijednosti za visinu grebena kod nerasta su iznosile $65 \mathrm{~cm}$, dok kod krmača $64 \mathrm{~cm}$. Duljina tijela prema ovom istraživanju iznosila je $128 \mathrm{~cm}$ za neraste, te $126 \mathrm{~cm}$ za krmače. Opseg prsa iznosio je 114 $\mathrm{cm}$ za obje kategorije, dok je visina križa kod nerasta iznosila $72 \mathrm{~cm}$, a kod krmača $71 \mathrm{~cm}$. Ovi rezultati ukazuju na vrlo male, odnosno neznatne razlike između nerasta i krmača, te da se tjelesne mjere crne slavonske svinje nisu značajno promijenile u odnosu na njezino formiranje i razvoj tijekom vremena, kao i u odnosu na druge lokalne pasmine iz okruženja. Stoga ih sustavnim uzgojno-selekcijskim radom treba kontrolirati i očuvati. Također, u radu je dan osvrt na brojno stanje u populaciji kroz povijest, kao i na uzgojne prakse, koje su u određenoj mjeri utjecale na vanjštinu crne slavonske svinje.
\end{abstract}

Ključne riječi: crna slavonska svinja, vanjština, tjelesne mjere, varijabilnost, fenotip

Primljeno: 17.12 .2020 .

Prihvaćeno: 22.12.2020. 